\title{
INFORMATION NEEDS AND SEEKING BEHAVIOUR AMONG MEDICAL STUDENTS OF PAMO UNIVERSITY OF MEDICAL SCIENCES PORT HARCOURT
}

\author{
Wiche Humphrey I. (Ph.D) ${ }^{\mathbf{1}}$ and Ray-Ogbonna Kelechi K. ${ }^{2}$ \\ Department of Library and Information Science, Ignatius Ajuru University of Education. \\ Rumuolumeni, Port Harcourt, Nigeria. \\ ${ }^{1}$ Email: humphrey.wichie@iaue.edu.ng \\ 2Email: kogbonna@pums.edu.ng
}

\section{Cite this article:}

Wiche H.I., Ray-Ogbonna K.K. (2021), Information Needs and Seeking Behaviour Among Medical Students of Pamo University of Medical Sciences Port Harcourt. British Journal of Library and Information Management 1(1), 1-15.

DOI: 10.52589/BJLIMQD2YVZOY.

\section{Manuscript History}

Received: 12 April 2021

Accepted: 29 April 2021

Published: 17 May 2021

Copyright $(9) 2020$ The Author(s). This is an Open Access article distributed under the terms of Creative Commons AttributionNonCommercial-NoDerivatives 4.0 International (CC BY-NC-ND 4.0), which permits anyone to share, use, reproduce and redistribute in any medium, provided the original author and source are credited.
ABSTRACT: The study investigated information needs and seeking behaviour of medical students of PAMO University of medical sciences Port Harcourt, Rivers State. Five objectives and five research questions guided the study. The researcher adopted a descriptive survey design for the study, with a population of 371 comprising hundred and three hundred level students, from which a census sampling technique was used to sample the entire population. Questionnaire titled "Information Needs and Seeking Behaviour of Medical Students" (INSBMS) was used to gather the data. Out of 371 copies of questionnaire administered, only 365 copies were found valid for the analysis. The study was analysed using multiple statistical tools, frequency distribution of the simple percentage and mean scores. The findings of the study revealed that the information needs of medical students of PAMO University include academic information, like courses they are to study, assignment, examination timetable, what book to use for the course, departmental programs, personal health information, medical news and laboratory practicals. They consult different sources when seeking information among which are medical textbooks, lecturers, classmates, they consult the library, school notice board, internet, ebooks and databases; the students use the library often and expressed satisfaction with library services. Based on the challenges encountered by the students, the following recommendations are therefore postulated that a course on information need and seeking behaviour be introduced in all institutions of higher learning, this course will reduce the frustration medical students undergo when in need of information. PAMO University library should train students on how to construct effective searches to enhance their use of electronic information resources in the library.

KEYWORDS: Information Needs and Seeking, Medical Students, Pamo University of Medical Sciences. 


\section{INTRODUCTION}

\section{Background to the Study}

Education is of great importance in the digital age. It is a tool for inculcating skills, competencies and knowledge required to survive, and it tells the tale and contributes to societal development and cultural improvement. Information is an invaluable commodity that is needed by every individual no matter the class, location and race. Igbokwe (2010) defined information as recorded experience used in decision making which means that any piece of information obtained must add something new to the existing knowledge of the user. Information is a processed data that is organised for easy retrieval in whatever format it may appear. It gives knowledge, which in turn brings development if only one recognises and uses it as a tool for development. Individuals need information for several reasons. However, the information needs and seeking behaviour could differ based on the particular profile. It depends on the environment the individual is in. According to El-Maamiry (2017), different disciplinary approaches are not necessarily monolithic in their information search patterns but differ according to the discipline. He further explained that information seeking behaviour is considered as a human attitude/behaviour to search for information in a purposeful way to find/fill the gap. This behaviour sometimes is very undefinable.

In the traditional settings, information access and use were limited but the continuous growth of the web and associated technologies such as mobile devices and social networking has placed information on the part of daily life of almost everyone. In the course of daily life and activities one accesses and uses a variety of information systems and services ranging from communications, such as e-mail, to social networking, such as Facebook, to a myriad of webbased database systems and information services (Chowdhury \& Chowdhury, 2011).

Each of these information systems is influencing the information seeking behaviour of students. Information seeking involves the need for the information, the purpose for seeking for the information, the type of information sought, the sources consulted and the ways or methods employed in getting the information. It is a basic activity indulged in by all people and manifested through a particular behaviour. Students seek information for various purposes. They make use of printed documents or e-documents to gather information. Researches reveal that with the emergence of web resources, the information seeking behaviour of students are changing rapidly all over the world (Moly, 2014). Olsen and Diekema (2012) mentioned that studying the way students find information is essential to understanding them as a user group, helping them find research more effectively and efficiently, and developing resources for their use. They also reported that most used sources of information by students are Google, Wikipedia, news websites, friends and family members, class notes, lecturers and selected subscription databases. Few students made use of physical libraries, librarians and information professionals, experts, books, magazines etc. Medical students need information that is pertinent to their desired goal such as information on laboratories, hospital, medicolegal, telemedicine and tablets. They may consult a variety of sources when seeking for their information needs such as the internet, lecturers, school notice board, hospital, textbooks, electronic resources, medical dictionaries, libraries, friends and colleagues. Mabawonku (2005) in Lawal (2012) highlights ways in which students seek information, which includes colleagues, library, friends, family members, internet etc. In the 2012 survey, over three quarters $(76 \%)$ of the scholarly readings were obtained through 
electronic means and just over half (51\%) of readings were read on a screen rather than from a print source or being printed out.

Information needs, information seeking behaviour and availability of information sources has to be studied since literature have proved that a naïve way of students' information seeking process emerged through empirical studies (Ismaila, 2019). It is also important due to the variety of access points, authentication procedure set by the publishers, search federations availed by the libraries and level of training and awareness provided to use the resources (Sankpal \& Punwatkar, 2015). It will help information providers, information brokers and libraries to redirect and or improve their services based on the current information needs of undergraduate students, which of course have been influenced by the emergence of ICT as identified by scholars. Newton (2019) asserts that to some extent, students' information seeking behaviour in terms of emergence of ICT has shifted their preferences of information forms from print to electronic. In their own vein Mahmood and Saeed (2014) expressed that the pursuit of knowledge has been revolutionized mainly through the vast expansion of data accessible via the Internet, undergraduates now employ a set of coping strategies in their search for information to fulfill their assignment requirements and as they prepare for examinations.

The study of information seeking behaviour of medical students is inadequate but specifically no study has a document on the information needs and seeking behaviour of students of PAMO University Medical Sciences, Port Harcourt. Thus, this study investigates the information needs and seeking behaviour of medical students of PAMO University

University libraries have roles to play in providing the students' information needs, University libraries are libraries established in the Universities to support their parents' Institution in meeting their goals. They are the essential tools/devices that support/aid education; they provide access to information and knowledge that support students' learning and knowledge acquisition. University Libraries have gained so much importance that students who want to succeed in their fields of endeavour must seek appropriate information and at the appropriate places and the library is certainly one of such places

Anyaoku (2018) stated that most students think the purpose of a university education is about enhancing one's career prospects; a step that will increase their chances of finding a job and going up the career ladder. However, University education entails much more; it is meant to broaden students' minds and horizons, entrench critical thinking that will help to analyse and solve problems constructively, thus empowering them to change the world, to acquire knowledge independently and to develop the confidence to challenge authority or dogma.

The landscape of learning keeps getting wider and richer, involving multiple contexts, contents, models and sources. Learning over the years has become a way of life. Moreover, in our quest for knowledge, we must differentiate between education and learning. Education or Instruction is something that an individual gets from an outside source, a school or college or some other set norms or standards. Learning on the contrary, is an informal process that evolves at the personal level, for which there are no set standards. One learns from birth to death. A tutor imparts education, whereas an individual learns from his surroundings. Education is what people do to you and learning is what you do for yourself, Anyaoku (2018) concluded. 
Information in the university library is provided in many formats, there are print collections in all areas of knowledge. This is in addition to providing access to information in electronic formats like online databases. Academic libraries also provide quiet, conducive and safe spaces for studying as well as provide support services; circulate materials and resources that support academic study. According to Obama (2005) an effective and efficient university library is an essential component of any high-profile academic institution to serve the students, researchers and lecturers. Students in higher institutions of learning must be conversant with the different resources and tools that can help them acquire the information they need, to complete an assignment and other research work easily and efficiently. Students need to know the appropriate resources or materials for specific academic work. (This means that students should be highly literate in using various information resources). An institution may have the best-stacked library, if the students are not using the books and other resources at the library; such a library becomes a storehouse. According to Anyaoku (2015), there is a need to help medical students imbibe good library use culture which involves resource use. This is because there are many benefits in the use of medical library resources which have institutionalized access to health information. Libraries have quality collections and librarians impart the skills needed to access information in the new environment. This can empower students in the ability to identify, locate and use information effectively. In medical education and health care, this is very important because of the emphasis on evidence-based practice, which requires information skills to harness evidence. Students require information for various purposes, which may include for education or for recreation. They also seek information through many channels such as print, electronic and audio visual, internet, ebook, database etc. The library is one source of information set up to provide information needed by students; fortunately, the academic library is equipped with all of them. The academic libraries are maintained and administered by their parent institutions to meet the information and research needs of students and staff Obi (2013) mentioned. They are the life wire of their parents' institutions (Ononogbo \& Akanwa, 2016). Ahiauzu (2002) states that University libraries provide a service of lending and reference materials appropriate to the needs of staff and students of the institution that established them.

PAMO University of Medical Sciences is a Medical University established in 2017 and domiciled in Port Harcourt, Rivers State, Nigeria. PAMO University of medical Sciences is a citadel of excellence in the delivery of tertiary education in the medical and health services in Nigeria. PAMO University where nothing is spared to bequeath a lasting quality education to medical scholars is equipped with sophisticated teaching aids, fully equipped laboratories, well-stacked libraries, and ICT solutions. The University library is well equipped with medical books (for different faculties and departments like Anatomy, Physiology, Biochemistry, Nursing, Pharmacology, Medical Laboratory, Medicine and Surgery etc.) medical journals. The e-library is connected to the internet with medical databases like Hinari/research 4life, PubMed, science direct, e-books, etc. Pamo University library is a special academic library that focuses on medical information. It is a learning resource. In line with the vision of the university, it provides knowledge to support the achievement of excellence. Student, staff and researchers make use of the library for learning, teaching, research and development. The services of the library include the following: Book loan services, Reference services, E-library access to all students, Expert servicing, Information literacy training services, Internet research skills training services, amongst others. 
All the students register to use the library, and they are expected to keep the rules and regulations governing the library. The library is calm, peaceful and conducive for studying, research and knowledge acquisition. The use of the library by students helps them to update their knowledge and competence. Various researches have been carried out in various institutions on the information needs of medical students. However, no research has been done in PAMO University to ascertain the information needs and seeking behaviour of the medical students. The study therefore is designed to investigate the information need and seeking behaviour of students in PAMO University of Medical Sciences Port Harcourt Rivers State.

\section{Statement of the Problem}

Information seeking behaviour encompasses individual's approaches to express information needs, seek information, evaluate, select and finally put to use. Lots of challenges have accompanied these approaches. Academic environment is dynamic and full of innovative practices; it affects its community members', especially medical students. It is therefore desirable to understand the purpose for which information is required, the environment in which the user operates, users' skills in identifying the needed information, channels and sources preferred for acquiring information, and barriers to information. Errors during the course of medical practice are common and can lead to adverse events in medical practices. Insufficient information and lack of knowledge of medical routines can serve as major contributing factors to the incidence of errors that occur during medical practices. Medical Students hope to be medical practitioners and therefore may need medical information related to their chosen career such as hospital, health, laboratories, academic, etc. This would help them to perform better but may not be feasible without the availability of information sources such as textbook, journals, newsletters, internet etc., to meet their information needs. PAMO University library is geared towards providing students with their information needs. Whether the students use the library, whether the library meets the information needs of the students which could result in their preferring other sources of information to meet their needs is unknown to the researcher. Students need immediate access to information in various sources and formats required to be effective and efficient in their academic pursuit as well as be better in their desired goal. In this light, Gardner (2017) stated that there is a need for better understanding of the information needs and information-seeking behaviors of medical surgical nurses. From literature, there has been very little comprehensive study on the information needs and seeking behaviour of medical students and it requires further empirical investigation (Adebayo, Michael \& Akole, 2017). No study has been carried out to find out the information needs and seeking behaviour of medical students in PAMO University, the study therefore sought to bridge this gap.

\section{Aim and Objectives of the Study}

The purpose of the study is to determine the information needs and seeking behaviour of medical students in PAMO University of Medical Sciences. The specific objectives are to:

1. Identify the information needs of medical students in PAMO University.

2. Find out the sources of information used by the medical students in PAMO University

3. To determine the extent to which the students use the library in PAMO University

4. Ascertain the students' level of satisfaction with the use of library services. 
5. Discover the challenges students encounter in utilizing the library resources in PAMO University

\section{Research Questions}

The following research questions guided the study:

1. What are the information needs of medical students of PAMO University of Medical Sciences?

2. What are the sources of information used by the medical students of PAMO University of Medical Sciences?

3. To what extent do medical students of PAMO University of Medical Sciences use the library?

4. How satisfied are medical students of PAMO University of Medical Sciences in the utilisation of library services?

5. What are the challenges medical students of PAMO University of Medical Sciences encounter in utilizing library resources?

\section{Significance of the Study}

The study will help information providers, information brokers, libraries and other sources of information to redirect and or improve their services based on the current information needs of undergraduate students identified in this study. It will also help the libraries to know the format to package their information to suit the needs of the students. The library management will see it as evidence to know the extent of utilisation of the library by students as well as the challenges they face when using the library. It will also add to an existing body of knowledge in the area of information needs and seeking behaviour especially of medical students.

\section{CONCEPT OF REVIEW}

\section{Information}

Information is defined as facts someone provided or learned about something. It is knowledge obtained from investigation study or instruction. It can also mean communication or reception of knowledge or intelligence. According to Cambridge English dictionary, information is fact, news, knowledge, and details obtained from someone about something. Mirriam-Webster's dictionary defines information as data news fact, a collection of factual knowledge about something. Information according to Ukachi (2007) is an important resource for human growth. Therefore, information is a process where data and ideas, new knowledge, intelligent messages could be contained in a book or non-book materials, they could also come as records.

\section{Information Needs and Seeking Behaviour}

Information seeking behaviour is defined as how people search for and utilize information. There are three aspects of information seeking behaviour, information need, information 
seeking and information use. Information need is an individual or group's desire to locate and obtain information to satisfy a conscious or unconscious need. On the other hand, information access differs from person to person according to their needs. Information seeking is like a communication behaviour, which is affected by different factors. People have diverse reasons for seeking information, the kind of information they sought, the ways they sought for information and where the sought for information differs from person to person.

\section{Sources of Information of Students}

Information sources can be defined as suppliers or generators of information in order to meet a perceived gap in knowledge or an information need. Activities that are undertaken to identify relevant information to satisfy a perceived need are information-seeking behaviors. Kommers and Isaiah (2010) observed that students with the zeal to acquire knowledge seek information regularly at the library; they visit the library on a daily basis to meet their information needs. They acquire information from books, journals, newspapers, and the internet.

\section{Empirical Review}

Oluwaseye, Akanni, and Busuyi (2017) investigated information needs and seeking behaviour of medical students at College of Medicine, University of Ibadan, Nigeria. Descriptive Survey design was used: five research questions were raised to achieve the five specific objectives stated. The findings from this study revealed that information needs of medical students of the University of Ibadan have many facets. The first on the list being medical information, followed by assignment and academic projects, these were the main purposes students seek for information. The Internet was mostly used by medical students out of other sources when seeking for Information.

Gardner (2017) explored the information-seeking behaviors of nurses when delivering patient care on medical-surgical units to inform the development of clinical decision support systems for medical-surgical acute care nurses. Findings revealed that nurses most often search for information in order to support a patient's treatment and the provision of a patient's care. Information regarding current and new orders and the schedule of a patient's care were the most frequently accessed types of information. Nurses in the study most often accessed electronic sources and utilized information in a computerized format.

El-Maamiry (2017), the Information-Seeking Behaviour of Students: A Case of University of Dubai. Descriptive survey design was adopted for the study. The population comprised students of University of Dubai, College of Business Administration and few from College of Information Technology. Ten students and a reference librarian were used to pre-test the questionnaire. Based on their feedback, the questionnaire was revised to the final form. Respondents were asked to fill the questionnaire, which includes three parts. First, demographic information; secondly, information resources use; and third barriers to use electronic resources. Participants of this study were randomly chosen amongst students of the University. Respondents were asked to express their opinions regarding the difficulties they face in using electronic resources. They mentioned that barriers of information seeking, mainly cited that they are facing difficulties in choosing databases (20\%), lack of searching skills (18\%), identifying reliable articles $(12.8 \%)$ of search results and $4 \%$ cited lack of qualified staff. $45.2 \%$ cited that they are not facing any problem at all. 
Sigh, Kumar and Khanchandani (2015) carried out a study on the information needs and information seeking behaviour of foreign students. A survey method was used for the study. It was found that post-graduate students needed information regarding their program of study while research scholars needed information for writing research articles and for doing their research work. Most of them sought information through the internet. Research scholars used electronic resources such as databases, e-journals and e-theses and dissertations. $88.6 \%$ of the respondents also used books for seeking information. Their use of the library was limited with complaints about library staff and too few computer terminals.

Moly (2014) surveyed Information needs and information seeking behaviour of Information Science students in Haramaya University. The study showed that more than half of the students visited the library every day. Students mainly used reference services from the library and for which they depended on reference sources. The main purpose of visiting the library was for writing assignments/research and study. The students used the library resources including books and journals and the internet to meet their information needs. Majority of students felt that there was a need for training for the efficient access and use of library materials. Information science students also mentioned that the number of books and journals available in their field of study were not sufficient.

Das and Jadab (2016) studied information seeking behaviour of students of law in digital environment at the University of Dhaka. Students were asked to mention the preference for format of information. The study indicated that the highest level of preference of information formats students mentioned was electronic format 83(45.36\%), followed by print formats (40.43\%). In addition to that, only 26(14.21\%) students preferred both print and electronic formats. According to the study, students encounter during information seeking and use. The most common problem students faced was a Lack of currency of information (45.9\%). Other major problems included unavailability of open access legal information sources, accounting for $22.40 \%$ of total respondents. In addition, $14.21 \%$ stated it was so time consuming to find information, $10.38 \%$ faced difficulty for constructing effective searches, and $4.38 \%$ got bored with the scattering of information in many sources.

Adam (2017) examined the undergraduate students' perception on library service quality from three dimensions, which are library information resources, services and facilities that are available for use in YMSU Library whether the users were satisfied with the quality of library service delivery or not. From the findings of the study, the researcher concluded that the general perception of undergraduate students towards the use of facilities, resources and services of the YMSU library, city campus is highly satisfactory.

Anyaoku (2015) studied the extent the library is achieving its aims. The research is a survey of undergraduate students' awareness and use of medical library resources in the College of Health Sciences, Nnamdi Azikiwe University, Nigeria. Results show that $84.8 \%$ of the students use the library. Regular users constitute $44.1 \%$ while occasional users are $40.7 \%$. Respondents' major activities in the Medical library are reading personal textbooks $(83.9 \%)$, newspapers $(67.1 \%)$, sourcing information for research or project work $(65.8 \%)$ and class assignments $(65.3 \%)$. Major barriers reported by the student on the effective use of the medical library are lack of computer / Internet (75.6\%) and lack of current materials $(60.7 \%)$. Improved facilities and resources may motivate the students to fully exploit the tool that is meant to provide information support for their studies and for practice of evidence based medicine upon graduation. 


\section{Methodology}

This study was a descriptive survey. The target population for this study consisted of medical students in two hundred (200) and three hundred (300) levels in PAMO University of medical sciences. The sampling technique used was census sampling techniques and the sample size of 371 respondents were drawn from the entire population. A standardized questionnaire titled, 'Information Needs and Seeking Behaviour of Medical Students' was used as the instrument of the study. The instrument consisted of two sections; A and B sections. Section A elicited socio-demographic information from the respondents, while section II, gathered information on information needs and seeking behaviour of medical students. A total of 371 copies of questionnaires were administered to the respondents. While 365 copies were completed and retrieved, six (46) copies of the questionnaires were not returned by the respondents. The instrument for this study was validated by the research supervisor supervisor. Test-retest method of reliability was adopted in this study. In doing so, the researcher administered twenty (20) questionnaires to students who were not part of the respondents and after two weeks intervals; the researcher administered the questionnaire to the respondents for the study. The initial and second scores were collated and subjected to Pearson product moment correlation analysis, and a reliability coefficient of 0.95 was obtained. Data obtained were analyzed with the aid of the statistical package for social sciences (SPSS) version 23.0, using statistics such as simple percentage, mean point value, and cross tabulation.

\section{RESULTS AND FINDINGS}

Table 1 Demographic Information of the Respondents

\begin{tabular}{ll}
\hline Gender & \\
\hline Male & $95(26 \%)$ \\
Female & $270(74 \%)$ \\
& \\
Age & \\
$15-20$ & $65(18 \%)$ \\
$21-25$ & $175(48 \%)$ \\
$26-$ above & $30(8 \%)$ \\
& \\
Department & \\
Medical and Surgery & $9(25 \%)$ \\
Anatomy & $89(24 \%)$ \\
Nursing & $75(21 \%)$ \\
Medical Laboratory & $58(16 \%)$ \\
Physiology & $52(14 \%)$ \\
\hline
\end{tabular}

Table 1 shows the demographic information of the respondents and revealed that most of the respondents were female (74\%) between the age range of 21-25 (48\%) the department of medical and surgery $(25 \%)$ dominated the study. 
Table 2: Mean Scores of Information Needs of Medical Students

\begin{tabular}{llllllll}
\hline $\begin{array}{l}\text { Indicate how often you need the } \\
\text { following information? }\end{array}$ & $\begin{array}{l}\text { Very } \\
\text { often }\end{array}$ & Often & Occasionally & Never & Mean & Decision \\
Academic Information & 151 & 141 & 69 & - & 3.2 & Accept \\
Research information & 105 & 124 & 136 & - & 2.9 & Accept \\
Personal health information & 122 & 156 & 87 & - & 3.1 & Accept \\
Laboratories & 141 & 145 & 79 & - & 3.1 & Accept \\
Hospital Policies & 49 & 96 & 155 & 65 & 2.3 & Reject \\
Radiography & 11 & 91 & 141 & 122 & 1.9 & Reject \\
Medicolegal & 15 & 99 & 151 & 100 & 2.0 & Reject \\
Medical news & 71 & 125 & 131 & 38 & 2.6 & Accept \\
\hline
\end{tabular}

The table shows the information needs of medical students in PAMO University are mostly centred on academic information (3.2) followed by laboratories (3.1), personal health information (3.1), research information (2.9), medical news (2.6). Hospital policies (2.3), medicolegal (2.0) radiography (1.9) were not necessarily needed by students according to the study. It can therefore be stated that the information needs of the students were on academics, laboratories, personal health, research and medical news. Hospital policies, medicolegal and radiography were not much sought by the students.

Table 3: Mean Scores of the Sources of Information of Medical Students

\begin{tabular}{|c|c|c|c|c|c|c|}
\hline $\begin{array}{l}\text { How often do you use the following } \\
\text { sources of information? }\end{array}$ & $\begin{array}{l}\text { Very } \\
\text { often }\end{array}$ & Often & $\begin{array}{l}\text { Occasionall } \\
\mathbf{y}\end{array}$ & Never & $\begin{array}{l}\text { Mea } \\
\text { n }\end{array}$ & Decision \\
\hline Print textbook & 158 & 142 & 65 & - & 3.2 & Accept \\
\hline Print journal & 9 & 75 & 113 & 165 & 1.8 & Reject \\
\hline e-book & 91 & 118 & 144 & 14 & 2.7 & Accept \\
\hline e-journal & 56 & 110 & 134 & 65 & 2.4 & Reject \\
\hline Newspaper and magazine & 51 & 92 & 135 & 87 & 2.3 & Accept \\
\hline Library & 150 & 145 & 52 & 18 & 3.1 & Accept \\
\hline Internet & 159 & 148 & 58 & - & 3.3 & Accept \\
\hline Library website & 9 & 143 & 151 & 62 & 2.3 & Reject \\
\hline Social media & 5 & 78 & 161 & 121 & 1.9 & Reject \\
\hline Hospital & 6 & 78 & 162 & 119 & 1.9 & Reject \\
\hline Database & 6 & 57 & 229 & 73 & 2.0 & Reject \\
\hline Science Direct & 4 & 58 & 220 & 83 & 1.9 & Reject \\
\hline Lecturers/lecture notes & 114 & 154 & 97 & - & 2.8 & Accept \\
\hline Classmates/colleagues & 115 & 157 & 93 & - & 2.8 & Accept \\
\hline Notice board & 110 & 151 & 81 & 23 & 2.9 & Accept \\
\hline Youtube & 7 & 85 & 181 & 92 & 2.0 & Reject \\
\hline
\end{tabular}

Table 3 above shows the mean scores of information sources of medical students of PAMO university in order of importance as discovered in the study: Internet (3.3), print textbook (3.2), library (3.1), notice board (2.9), classmates (2.8) and e-book (2.7). E-journal (2.4), newspaper 
and magazine (2.3), library website (2.3), database (2.0), Youtube (2.0), social media (1.9), hospital (1.9), and Science direct (1.9) were not usually accessed by the students.

Table 4: Mean Scores of the Extent of Library Use by Medical Students

\begin{tabular}{lll}
\hline How often do you visit the library? & Yes & No \\
\hline Daily & $195(53 \%)$ & $170(47 \%)$ \\
Weekly & $95(26 \%)$ & $270(74 \%)$ \\
Fortnightly & $34(9 \%)$ & $331(91 \%)$ \\
Monthly & $29(8 \%)$ & $336(92 \%)$ \\
Rarely & $9(2 \%)$ & $356(98 \%)$ \\
Never & $3(1 \%)$ & $362(99 \%)$ \\
\hline
\end{tabular}

Table 4.4 shows the frequency of use of PAMO university library and revealed that most of the respondents use the library daily (53\%), followed by weekly $(26 \%)$, fortnightly (9\%), monthly (8\%), rarely (2\%) and never (1\%). This shows that medical students of PAMO University of medical sciences use the library often.

Table 5: Mean Scores of the Level of Satisfaction of Library Services by Medical Students

\begin{tabular}{lllllll}
\hline $\begin{array}{l}\text { How would you agree or disagree to your } \\
\text { satisfaction with the following library services }\end{array}$ & SA & A & D & SD & Mean Decision \\
\hline e-resources & 92 & 108 & 109 & 56 & 2.6 & Accept \\
Internet & 125 & 156 & 55 & 29 & 3.0 & Accept \\
Reprographic services & 77 & 115 & 144 & 29 & 2.6 & Accept \\
Reference services & 19 & 115 & 132 & 99 & 2.1 & Reject \\
OPAC & 110 & 119 & 106 & 30 & 2.8 & Accept \\
Current awareness services & 25 & 126 & 155 & 59 & 2.3 & Reject \\
Power supply & 154 & 178 & 33 & - & 3.3 & Accept \\
Library orientation/instruction & 18 & 114 & 125 & 108 & 2.1 & Reject \\
\hline
\end{tabular}

Table shows the satisfaction level of medical students of PAMO University of medical sciences on the use of library services and reveals that the students were satisfied in power supply (3.3), internet (3.0), OPAC (2.8), e-resources (2.6) and reprographic services (2.6). They expressed dissatisfaction on current awareness services (2.3) and library orientation (2.1). 
Table 6: Mean Scores of the Challenges Facing Medical Students when Seeking for Information Needs

\begin{tabular}{lllllll}
\hline $\begin{array}{l}\text { What challenges do you face when seeking } \\
\text { for information needs }\end{array}$ & SA & A & D & SD & Mean \\
\hline $\begin{array}{l}\text { Inadequate sources of information on medical } \\
\text { matters in the library }\end{array}$ & 78 & 110 & 14930 & 2.6 & Accept \\
$\begin{array}{l}\text { Lack of current materials } \\
\text { Unconducive environment of the library }\end{array}$ & 8 & 74 & 166114 & 1.9 & Reject \\
Inadequate information on databases & 67 & 74 & 166114 & 1.9 & Reject \\
Irrelevant information on the internet & 150 & 147 & 56 & 12 & 3.2 & Accept \\
Lack of internet search skills & 145 & 178 & 33 & 10 & 3.2 & Accept \\
\hline
\end{tabular}

Table 6 shows that the challenges students in PAMO university of medical science faced when seeking for their information needs were irrelevant information on the internet (3.2), lack of internet search skills (3.2), lack of current materials (1.9), inadequate sources of information on medical issues in the library (2.6), inadequate information on database (2.6) and unconducive environment of the library (1.9). The result therefore, shows that the challenges medical students face were irrelevant information on the internet, lack of internet search skills, inadequate sources of information and inadequate information on databases. Lack of current materials and unconducive environment was not perceived as a challenge by the students.

\section{DISCUSSION OF FINDINGS}

\section{Information Needs of Medical Students of PAMO University of Medical Sciences}

The finding of question one, revealed that the information needs of medical students of PAMO University were academics, laboratories, personal health, research and medical news. Hospital policies, medicolegal and radiography were not much sought by the students. This indicates that students need information mostly on academics, laboratories, health and medical news. The finding correlates with that of Escrootchi and Azar (2017) on the information needs of medical students in the emergency departments at teaching hospitals in Iran University of Medical Sciences and found that the majority of their information needs included laboratories and also correlate with Latif (2017) that found information needs of students to include academic and health matters.

\section{Sources of Information of Medical Students of PAMO University of Medical Sciences.}

The finding of question two revealed that the sources of information of medical students of PAMO University were Internet, print textbook, library, notice board, classmates, lecturers and e-book. The students did not usually access E-journal, newspaper and magazine, library website, database, YouTube, social media, hospital and science direct. This study correlates with Nsirim (2019) on the information needs, seeking behaviour and use of library and information science by students of Rivers State University, which revealed that students consulted the internet, notice board, lecturers and lecture notes to meet their information needs. 


\section{Use of Library by Medical Students of PAMO University of Medical Sciences}

The finding of question three shows the extent of use of the library by medical students of PAMO University of Medical Science. The findings revealed that the students use the library. The study is in line with that of Ismaila (n.d) on information needs and seeking behaviour of postgraduate students in Kwara State University, Malete. The study found that all the respondents being post graduate students of the University had the habit of using the library and a very negligible portion opine that they do not use the library. Ismaila (n.d) studied information needs and information seeking behaviour of postgraduate students in Kwara state University, Malete. All the respondents of the study i.e. postgraduate students of University are in the habit of using the library. Most of the respondents visit the library on a daily basis, some of the respondents visit the library every alternate day, others visit once in a week and occasionally a very negligible portion opine that they do not use the library at all. Anyaoku (2015) also indicated that a large percentage visits the Medical Library either regularly or occasionally.

\section{Satisfaction Level of Medical Students on the Use of Library Services}

Satisfaction level of medical students of PAMO University of Medical Sciences on the use of library services reveals that the students were satisfied with power supply, internet, OPAC eresources, and reprographic services. They expressed dissatisfaction on current awareness services and library orientation. The study correlates with that of Verma and Lalrokhawma (2018) on users' satisfaction with library resources and services: a case study of Lunglei Government College Library and revealed that, majority of the undergraduate students were highly satisfied with cleanliness of library environment, brightness of the library building, as well as the seating arrangement of the library. In addition, more than half of the users were satisfied with the knowledge and courtesy of library staff in providing information services. Less than half of the users were found to be satisfied with library collections both print and electronic, library reference services, internet service, photocopying service, and number computers available in the e-library.

\section{Challenges that Faced Medical Students when Seeking for Information}

Question five addressed the challenges the Medical Students faced when seeking for Information or when in need of information. This showed that irrelevant information on the internet, lack of internet search skills, inadequate sources of information and inadequate information on databases. The students did not perceive the unconducive environment as a challenge because the library is a serene environment. The study is in line with Anyaoku (2015) who reported major barriers faced by the students on the effective use of the medical library to include lack of computer and Internet, and lack of current materials. Noise was the least barrier to the use of the medical library.

\section{CONCLUSION}

Based on the findings of this study, it is clear that the information needs of medical students are academics, internet, laboratories and health. Their sources of information were the library and the internet. Lecturers always visit libraries to seek information but the challenges they faced included irrelevant information on the internet, lack of internet search skills, inadequate 
sources of information and how to source for information on databases. The study can be concluded that if medical students are provided with their information needs as identified in the study, they would perform better and be more informed in their professional pursuit.

\section{RECOMMENDATIONS}

Based on the findings of the study, the following recommendations are therefore postulated:

1. That a course on information need and seeking behaviour among undergraduate students, be introduced in all Institutions of higher learning in the country. A professional librarian who understands the fastest and easiest avenue to source Information will handle this course; this course will reduce the frustration that undergraduate students undergo when in need of information. This will bridge the gap in knowledge, which the researcher observed.

2. That PAMO University of Medical Sciences should provide for the students information on academics, personal health matters and research.

3. That PAMO University of Medical Sciences should provide for the students' Internet databases. Library should be well equipped with print textbooks and e-book. Lecturers as mentors to the students should continue to strive harder to be more informative to be able to serve as a formidable source of information to students. Library should also encourage students to access other sources of information like the journals, newspaper and magazines, etc.

4. That PAMO University of Medical Sciences library should be more innovative in packaging and repackaging of information as well as provide information materials for students in various forms. Advocacy and library instruction programmes should always be carried on to inform students that the library is the most reliable place where the most needed information can be sought.

5. That Pamo University of Medical Sciences should train students on internet search skills as this will encourage their usage of library electronic and online databases as well as electronic resources

\section{REFERENCES}

Adam, R. (2017) Assessment of library service quality and user satisfaction among undergraduate students of Yusuf Maitama Sule University (YMSU) library. Library Philosophy and Practice (e-journal).

Adebayo,J. O., Michael, A.J. \& Akole, B. O. (2017) information needs and seeking behaviour of medical students at College of Medicine, University of Ibadan, Nigeria. Journal of Applied Information Science and Technology, 10 (2), 49-62

Anyaoku, E. A. (2015) Evaluating Undergraduate students' awareness and use of medical library resources: A study of Nnamdi Azikiwe University, Nigeria. International Journal of Library Science, 4(3), 53-58 
Anyaoku, E.N. (2018) A new attitude to effective learning: the role of library services in the $21^{\text {st }}$ century learning environment/ International Journal of library science

Choukhande, V.G. (2008) Information needs and information seeking behaviour. Amravati, India: Shivneri Publisher.

Das, R.K.\& Jadab, A. (2016) Information seeking behavior of law students in the digital age: a user study at university of Dhaka. International Research: Journal of Library \& Information Science. 6(3), 381-396.

El-Maamiry, A.A. (2017) Information-seeking behaviour of students: a case of University of Dubai. Global Journal of Computer Science and Technology. 17(1), 1-7

Ibenne, S. K. (2018). Information Resource Development and management. Okigwe Imo State. Justman Publisher.

Jaccard, J. \& Jacoby, J. (2010). Theory construction and model building skills. New York: Guilford Press

Khoir, S., Du, J.T. \& Koronios, A. (2015) Linking Everyday Information Behaviour and Asian Settlement Processes: Towards Conceptual Framework. Journal Australian Academic \& Research Libraries. Vol. 46 Issue 2

Kommers, P. A. M., \& Isaias, P. (2010). Proceedings of the IADIS International Conference on e-Society. Porto, Portugal: IADIS. (International association for Development of the information society)

Manoj, K. S. (2015) A Study on Information Needs and Information Seeking Pattern of Public Library Barak Valley. Journal of Humanities and Social Science Volume 20, Issue 8.

Marshall, A. P., West, S. H., \& Aitken, L. M. (2011). Preferred information sources for clinical decision-making: Critical Care nurses' perceptions of information accessibility and usefulness. Worldviews on Evidence- Based Nursing, 8(4)

Newman, K. M., \& Doran, D. (2012). Critical care nurses' information-seeking behaviour during an unfamiliar patient care task. Dynamics, 23(1), 12- 17.

Obi, B.B. (2013). The library and its users. Hairloom.

Oduagwu, E. A. (2006) Library and Information management: in a globally networked society. Demmac publishers.

Oyadeyi, A.E., (2017). The Information Needs and Information Seeking Behaviour among the Students of Ondo State University of Science and Technology, Okitipupa 4 (1).

Samuel. E.O and Richard J.O., (2011) Information Needs and Information Seeking Behaviour and Use of Information Resources by MBA Students at a Nigerian University. An International Multidisciplinary Journal, Ethiopia.

Sawant, S. (2015). Krikelas' model of information seeking behaviors: Theories and trends. Hershey, PA: IGI Global

Scoulas, J. M., \& De Groote, S. L. (2019). The Library's Impact on University Students' Academic Success and Learning. Evidence Based Library and Information Practice, 14(3), 2-27

Unagha, A.O.\& Igwe, K. N. (2018) Anatomy of Libraries and Information Centres. Lagos. Zeh Communication.

Westenskow, D. (2012). Intensive care unit nurses' information needs and recommendations for integrated displays to improve nurses' situation awareness. Journal of the American Medical Informatics Association, 19(4), 583-590. 